\title{
New taxa of Chrysomelidae (Coleoptera) from Vietnam
}

\section{Новые таксоны Chrysomelidae (Coleoptera) из Вьетнама}

\author{
L.N. Medvedev

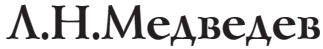

Institute for Ecology and Evolution, Russian Academy of Sciences, Leninsky prospect 33, Moscow 119071 Russia. Институт проблем экологии и эволюции РАН, Ленинский проспект 33, Москва 119071, Россия.

KEY WORDS: Chrysomelidae, Vietnam, new genus, new species, new records.

КЛЮЧЕВЫЕ СЛОВА: Chrysomelidae, Вьетнам, новый род, новые виды, новые данные.

ABSTRACT. Genus Vietoluperina gen.n. and 17 species from Vietnam: Platycorynus splendens, Colaspoides fulvus, Colaspoides pseudorufa (Eumolpinae), Galerucella quadripustulata, Oides fedorenkoi, Monolepta mirabilis, $M$. bacboensis, $M$. quinquefasciata, $M$. multisignata, $M$. fedorenkoi, $M$. binhphuoca, $M$. daklaka, Sermyloides nigricollis, S. tamdaoana, Vietoluperina polilovi, Aplosonyx fedorenkoi, Theopea clypealis spp.n. (Galerucinae) are described as new for science. Plagiodera miniaticollis (Hope, 1831) (Chrysomelinae) and Sinocrepis obscurofasciata (Jacoby, 1882) (Alticinae) are firstly recorded for Vietnam.

РЕЗЮМЕ. Род Vietoluperina gen.n. и17 видов из Вьетнама: Platycorynus splendens, Colaspoides fulvus, Colaspoides pseudorufa (Eumolpinae), Galerucella quadripustulata, Oides fedorenkoi, Monolepta mirabilis, M. bacboensis, M. quinquefasciata, M. multisignata, M. fedorenkoi, M. binhphuoca, M. daklaka, Sermyloides nigricollis, S. tamdaoana, Vietoluperina polilovi, Aplosonyx fedorenkoi, Theopea clypealis spp.n. (Galerucinae) описываются как новые для науки. Plagiodera miniaticollis (Hope, 1831) (Chrysomelinae) и Sinocrepis obscurofasciata (Jacoby, 1882) (Alticinae) впервые указываются для Вьетнама.

\section{Introduction}

Descriptions of a new genus and 17 new species from Vietnam are given below. All material is deposited in the author's collection (LM), including new materials collected in the last years by D. Fedorenko.

\section{Taxonomic part}

\section{Platycorynus splendens L.Medvedev, sp.n.}

\section{Figs 1, 12}

MATERIAL. Holotype (male): Vietnam, Lam Dong province, $35 \mathrm{~km}$ NW of Bao Loc, Loc Bao env. (11 $\left.{ }^{\circ} 50^{\prime} 12^{\prime \prime} \mathrm{N}, 107^{\circ} 38^{\prime} 25^{\prime \prime} \mathrm{E}\right)$, 650 km, 17-22.IV.2012, on light, leg. D. Fedorenko (LM)

DESCRIPTION. Head and upperside bright metallic red cupreous, underside darker, partly with green luster, labrum and palpi black. Antennae black with metallic luster.

Body oblong. Head with straight transverse furrow separating clypeus from frons and interrupted in middle, clypeus finely and very densely punctate, frons and vertex strongly punctate, interspaces of punctures narrower than their diameter and finely strigose, vertex flattened and slightly grooved anteriorly, anterior part of head with dense erect hairs, furrow above eye deep and broad. Antennae about half of body length, thickened from the $7^{\text {th }}$ segment, proportions of segments are as 5-2-7-5-6-5-10-9-9-9-10, $7^{\text {th }}$ segment elongate triangular and twice as long as wide, $8^{\text {th }}-10^{\text {th }}$ about 1.7 times as long as wide, apical segment 2.3 times as wide as long, with rounded apex. Prothorax 1.65 times as wide as long, broadest behind middle, bore, side margins rounded, surface convex, strongly and partly subrugosely punctured, with interspaces mostly smaller than punctures and convex. Scutellum triangular with rounded apex, shining and very finely punctate. Elytra 1.4 times as long as wide, parallelsided with rounded apex, bore, surface very strongly and deeply punctate and with a few feeble longitudinal costae or folds, interspaces of punctures distinctly raised, basal convexity developed, but very feeble. Segment 1 of fore and mid tarsi widened, slightly transverse. Mid femora with strong tooth on underside, mid tibiae deeply incised on middle of underside (Fig. 1). Claws appendiculate. Aedeagus (Fig. 12) with acute triangular apex, delimited on sides with unsclerotized areas. Length of body $6.3 \mathrm{~mm}$.

Diagnosis. This species belongs to a small natural group with modified mid legs and represented in Vietnam with 3 species: P. deletus (Lefevre, 1890), P. viridimicans Gressitt et Kimoto, 1961 and P. bacboensis L. Medvedev et Rybakova, 1985, but differs from all of them in color and especially with very strong punctures of upperside. It is very near to $P$. rugosus Kimoto et Gressitt, 1982, description of each was based only on 2 females, but differs at least with unusual color, obtuse apical segment of antennae, dense pubescence of head, rather feeble costae on elytra and smaller size $(6.3$ against $6.9-8.0 \mathrm{~mm}$ )

\section{Colaspoides fulvus L. Medvedev, sp.n.}

Fig. 13.

MATERIAL. Holotype (male): Vietnam, Binh Phuoc prov., Bu Gia Map National Park, IV.2009, leg. A. Polilov (LM).

DESCRIPTION. Entirely fulvous. Body elongate ovate. Head impunctate, with trace of groove on vertex, interocular space about as wide as transverse diameter of eye. Antennae reach middle of elytra, proportions of segments are as 11-5- 

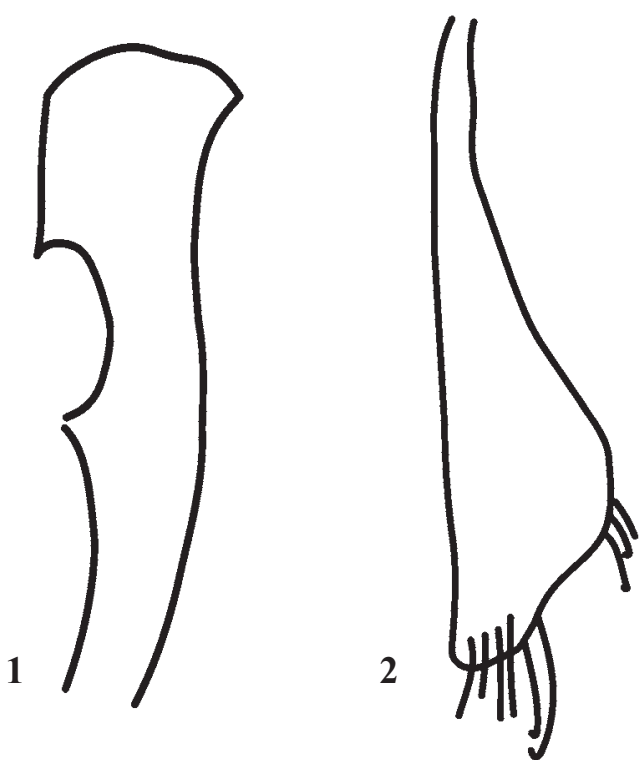

Figs 1-2. Tibia of males: 1 - mid tibia of Platycorynus splendens sp.n. ; 2 - hind tibia of Colaspoides pseudorufa sp.n.

Рис. 1-2. Голени самца: 1 - средняя голень Platycorynus splendens sp.n.; 2 - задняя голень Colaspoides pseudorufa sp.n.

13-13-17-17-20-15-15-13 (apical segment absent, preapical segments about 4-5 times as long as wide, segments 3-7 without a fringe of long hairs beneath. Prothorax twice as wide as long, broadest behind middle, side margins rounded, surface shining, with fine and very sparse punctures. Elytra 1.5 times as long as wide, broadly rounded on the apex, strongly and closely punctate, punctures on apical slope arranged in more or less regular rows. Propleurae impunctate, shining. Abdominal sternites simple, without tubercles, ridges or distinct hairy brushes, but sternites 1-3 with a few long and erect hairs, sides of sternites 4 and 5 feebly serrate, furrow of pygidium narrowed from base to apex, without ridge on bottom. All femora not toothed, hind tibiae simple, segment 1 of fore and mid tarsi moderately widened, elongate ovate, twice as long as wide. Aedeagus (Fig. 13) with elongate-triangular and very acute apex, its underside simple, evenly convex. Length of body $4.3 \mathrm{~mm}$.

DIAGNOSIS. Belongs to group 3 [Medvedev, 2003] and near C. rufofulvus L. Medvedev, 2003 from N. Vietnam, differs with smaller size, much more light color, impunctate head, very finely and sparsely punctate prothorax and other form and sculpture of aedeagus.

\section{Colaspoides pseudorufa L. Medvedev, sp.n.} Figs 2, 14.

MATERIAL. Holotype (male): Vietnam, Binh Phuoc prov., Bu Gia Map National Park, IV.2009, leg. A. Polilov (LM). Antennae broken, only 4 basal segments present.

DESCRIPTION. Entirely fulvous. Body elongate ovate. Head impunctate, with groove on vertex. Antennal segments 3 and 4 subequal, without a fringe of long hairs beneath. Prothorax 1.8 times as wide as long, broadest before base, surface with a few fine and very sparse punctures. Elytra 1.4 times as long as wide, broadly rounded at the apex, strongly and densely punctate, with 2-3 irregular rows near apex. Furrow of pygidium without distinct ridge on bottom. Abdominal sternites with brushes of hairs on two basal segments, but without tubercles or ridges on sternite 1 . Segment 1 of fore and mid tarsi widened, elongate ovate, 1.7 times as long as wide. Femora not toothed. Hind tibiae modified, with brush of long and partly curved hairs on apex and strongly widened in apical half (Fig. 2). Aedeagus - Fig. 14. Length of body $4.8 \mathrm{~mm}$.

DIAGNOSIS. This species belong to group 3 Belongs to group 3 [Medvedev, 2003] and near species group with hairy brush on hind tibiae of male. This group includes 4 species, one of them, C. crassifemur Tan et Wang, 1984 from China has very thick femora. Other species might be divided as follow:

1(4) Antennal segment 3-7 with a fringe of long hairs beneath. Basal abdominal sternite of male with tubercle or ridge at hind margin.

2(3) Apex of hind tibia of male moderately widened on apex, with groove on dorsal side. Apex of aedeagus complicate. S. China, N. Vietnam ......... C. pilicornis Lefevre, 1882

3(2) Apex of hind tibia of male simple. Apex of aedeagus simple. Middle Vietnam (Gialai-Contum prov.) ...

C. seticornis L. Medvedev, 2003

4(1) Antennal segment 3-7 (or at least 3-4) without a fringe of long hairs. Basal abdominal sternite of male without tubercles or ridges.

5(6) Abdominal sternites of male without brushes of hairs. Apex of hind tibia of male not widened. S. China

C. rufa Gressitt \& Kimoto, 1961

6(5) Abdominal sternites 1 and 2 with brushes of hairs in male. Apex of male tibia strongly widened. S. Vietnam ....

C. pseudorufa sp. $\mathbf{n}$.

\section{Galerucella quadripustulata L. Medvedev, sp.n.} Fig. 6.

MATERIAL. Holotype (female): Vietnam, Tam Dao, 900 m, 4.VI.1981, leg. L. Medvedev (LM).

DESCRIPTION. Head, prothorax and scutellum red fulvous, antennae black with 3 basal segments more or less fulvous, elytra black with large spot before middle and smaller one on apical slope fulvous (Fig. 6), breast fulvous, abdomen black, legs black with femora more or less fulvous, pubescence of elytra black on dark areas and white on fulvous ones.

Body elongate ovate, widened to behind. Clypeus triangular with straight anterior margin, frontal tubercles rather narrow, subquadrate, delimited posteriorly with transverse impression, vertex not strongly punctate, depressed in middle. Antennae reach middle of elytra, proportions of segments are as 10-4-10-10-9-7-7-7-6-6-10, preapical segments about twice as long as wide. Prothorax 1.85 times as wide as long, broadest before middle, with all angles acute, bearing seta, surface shining, with very short hairs only on margins and in basal triangle, with deep impression on each side and shallow impression before scutellum, punctate along sides and in basal triangle. Scutellum trapeziform, punctate and pubescent. Elytra 1.4 times as long as wide, broadest in apical quarter, surface with dense pubescence and very dense punctures, all interspaces much narrower than diameter of punctures. Epipleurae narrowed to behind, but reach almost apex. Length of body $6.2 \mathrm{~mm}$.

DIAGNOSIS. This species is just formally placed in Galerucella, having most part of prothorax glabrous and elytra spotted, what is untypical for all species of this genus. Very possibly it is a new genus, but I have no enough material for such decision.

\section{Oides fedorenkoi L. Medvedev, sp.n.} Fig. 7.

MATERIAL. Holotype (female): South Vietnam, Lam Dong Prov., 5 km N Lang Lanh, Nui Bat Natural Reservation, 1400-1600 m, 12-22.IV.2008, leg. D. Fedorenko (LM).

DESCRIPTION. Head black with fulvous clypeus and labrum, maxillar palpi fulvous with 2 apical segments black, 
antennae black with 5 basal segments fulvous, prothorax black with all margins fulvous, scutellum fulvous, elytra metallic blue with broad lateral margin and apical area fulvous (Fig. 7), metasternum and abdomen black with margins more or less fulvous, metapleurae fulvous, but piceous in middle, legs fulvous, partly variegated with black.

Body elongate ovate. Head impunctate, labrum excavated in middle of anterior margin, clypeus convex with straight anterior margin, frontal tubercles transverse and triangular, delimited posteriorly with straight impressed line, vertex longitudinally impressed. Antennae reach anterior third of elytra, proportions of segments are as 10-3-7-7-7-7-6-6-5-5-6, preapical segments about twice as long as wide. Prothorax 2.4 times as wide as long, broadest behind middle, side margins feebly rounded, anterior and posterior angles rounded, surface shining, extremely finely and sparsely punctate. Scutellum triangular. Elytra 1.5 times as long as wide, distinctly narrowed to behind, very finely, partly indistinctly punctate. Epipleurae at middle about $1 / 10$ as wide as elytron. Length of body $11.5 \mathrm{~mm}$.

DIAGNOSIS. Near $O$. duporti Laboissiere, 1920, in which however upperside fulvous with 2 or 4 spots on prothorax and 5 spots on elytra black.

Monolepta mirabilis L. Medvedev, sp.n. Figs 8, 15.

MATERIAL. Holotype (male): South Vietnam: Lam Dong Prov., $5 \mathrm{~km}$. N of Lang Lanh, Bi Doup-Nui Bat Natural Reservation, 14001600 m., 26.III-23.IV.2008, leg. D. Fedorenko (LM).

DESCRIPTION. Pale flavous, head, antennae, scutellum, all margins of elytra, including humeral tubercle (Fig. 8), breast, tibiae and tarsi black. Body elongate. Head shining, practically impunctate, clypeus convex, interantennal space moderately broad, frontal tubercles triangular, poorly delimited from each other and on sides, but distinctly delimited behind with transverse groove, interocular space twice as wide as transverse diameter of eye. Antennae reach middle of elytra, proportions of segments are as $10-5-5-12-12-12-12-12-$ 11-10-14, preapical segments about 3.5 times as long as wide. Prothorax 1.7 times as wide as long, broadest near middle, sides feebly rounded, surface shining, with impression on each side, shining, finely and rather densely punctate. Scutellum triangular, impunctate. Elytra 1.6 times as long as wide, almost parallel-sided, surface shining, finely and not very distinctly punctate. Aedeagus (Fig. 15) has quite unusual form, with long spoon-like appendix on apex. Length of body $3.5 \mathrm{~mm}$.

DIAGNOSIS. This species have to be placed near M. dalatica Kimoto, 1989, but much smaller, with entirely fulvous abdomen and quite unusual aedeagus.
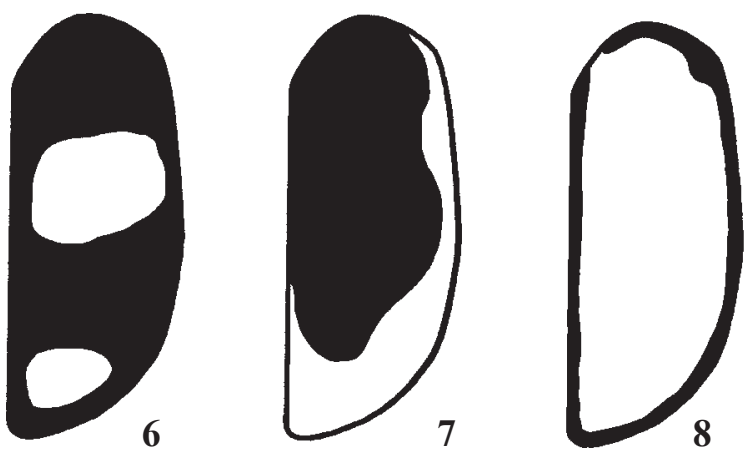

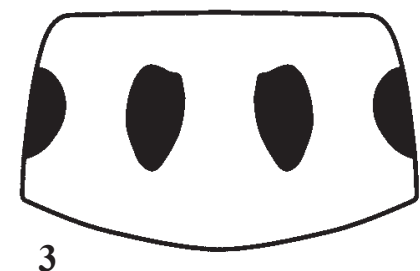

3

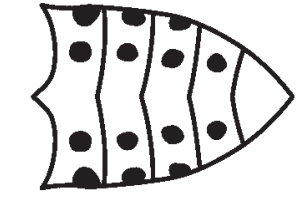

5

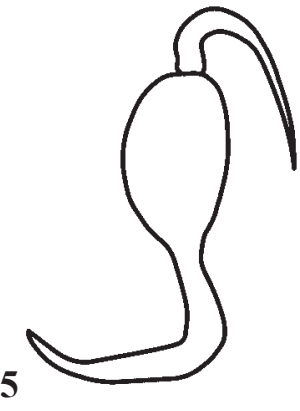

Figs 3-5. Monolepta spp: 3-4-M. multisignata sp.n.; 5-M. fedorenkoi sp.n.; 3 - prothorax; 4 - abdomen; 5 - spermatheca.

Рис 3-5. Monolepta spp: 3-4 - M. multisignata sp.n.; 5-M. fedorenkoi sp.n.; 3 - переднеспинка; 4 - брюшко; 5 сперматека.

\section{Monolepta bacboensis L. Medvedev, sp.n.} Fig. 9.

MATERIAL. Holotype (female): Vietnam, Hatuyen province, Hagiang, V.1975, leg. L. Medvedev (LM).

DESCRIPTION. Head black with piceous labrum and vertex, antennae and prothorax black, elytra tricolor: basal third red, large middle part fulvous, apical 1/5 black (Fig. 9), epipleurae red, underside fulvous, legs black with all trochanters and hind femora fulvous, scutellum red.

Body elongate ovate. Clypeus convex, its anterior part impunctate, posterior part with sparse punctures bearing short hairs, interantennal space convex, broader than antennal insertion, frontal tubercles transversely triangular, feeble, delimited posteriorly with transverse impression, vertex impunctate, interocular space twice as wide as transverse diameter of eye. Antennae almost reach apical slope of elytra, proportions of segments are as 13-4-6-13-15-14-14-13-10-10-12, preapical segments about 5 times as long as wide. Prothorax 1.8 times as wide as long, broadest behind middle, sides feebly arcuate, surface with feeble impression on each side, finely and rather densely punctate. Scutellum triangular, impunctate. Elytra 1.45 times as long as wide, surface shining, finely and densely punctate. Segment 1 of hind tarsus 1.5 times as long as next segments combined. Length of body $6.8 \mathrm{~mm}$.
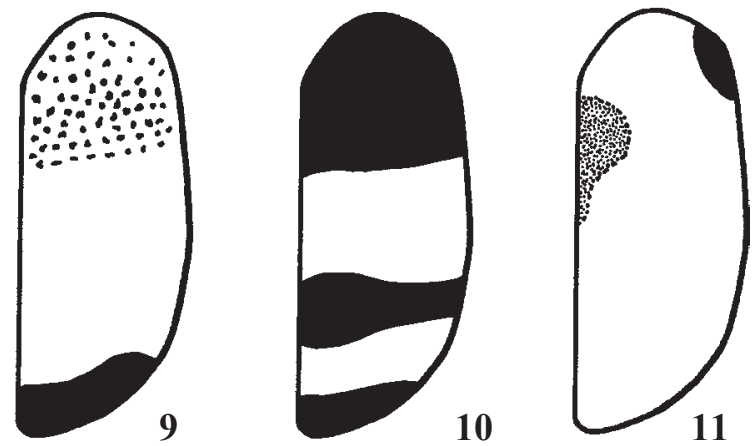

Figs 6-11. Elytral pattern: 6 - Galerucella quadripustulata sp.n.; 7 - Oides fedorenkoi sp.n.; 8 - Monolepta mirabilis sp.n.; 9 Monolepta bacboensis sp.n.; 10 - Monolepta quinquefasciata sp.n.; 11 - Monolepta binhphuoca sp.n.

Рис 6-11. Рисунок надкрылий: 6 - Galerucella quadripustulata sp.n.; 7 - Oides fedorenkoi sp.n.; 8 - Monolepta mirabilis sp.n.; 9 - Monolepta bacboensis sp.n.; 10 - Monolepta quinquefasciata sp.n.; 11 - Monolepta binhphuoca sp.n. 
DIAGNOSIS. Near M. pseudornata Kimoto, 1969, differs with tricolor elytra, entirely fulvous underside, bicolor head, broad interocular space and much larger size.

\section{Monolepta quinquefasciata L.Medvedev, sp.n.} Fig. 10.

MATERIAL. Holotype (female): Vietnam, Song Chau, V.1975, leg. L. Medvedev (LM). Paratypes: Vietnam, upper stream of river Con, 5-9.XII.1963, leg. O. Kabakov, 2 females (LM); Vietnam, SW Cui Chau, 200 m, 7.X.1963, leg. O. Kabakov, 1 female (LM); NW Thailand, Mae Hong Son, Ban Huai Po, 1600-2000 m, 9-16.V.1991, leg. J. Horăk, 1 female (LM)

DESCRIPTION. Fulvous, labrum piceous, scutellum black, elytra with 3 black bands: basal band occupies anterior third of elytra, more narrow band placed behind middle, last band occupies apex of elytra (Fig. 10), meso- and metasternum black, pygidium and abdomen red, also abdominal tergites more or less reddish, hind tibiae and tarsi often more or less blackish. Body elongate ovate. Head shining, impunctate, frontal tubercles absent, interantennal space almost flat and rather broad, interocular space more than twice as wide as transverse diameter of eye. Antennae reach a little behind middle of elytra, proportions of segments are as 12-5-5-11-10-10-10-10-9-9-11, preapical segments about 3 times as long as wide. Prothorax 1.6 times as wide as long, broadest near base, side margins feebly rounded, surface without impressions, shining, not strongly and moderately densely punctate. Scutellum triangular. Elytra 1.4 times as long as wide, broadest near middle, surface finely and densely punctate. Pygidium triangular. Segment 1 of hind tarsus as long as next segment united. Length of body $3.3-3.8 \mathrm{~mm}$.

DIAGNOSIS. Just for 50 years I unsuccessfully tried to find a male of this species. It has same elytral pattern as M. cavipennis Baly, 1878, which however is much larger and has black head and fulvous abdomen. I placed it near $M$. bifasciata (Hornstedt, 1788), which has only two black bands on elytra and entirely fulvous underside.

\section{Monolepta multisignata L. Medvedev, sp.n.} Figs 3, 4.

MATERIAL. Holotype (female): South Vietnam, Lam Dong Prov., 5 km N Lang Lanh, Nui Bat Natural Reservation, 1400-1600 m, 26.III-23.IV.2008, leg. D. Fedorenko (LM).

DESCRIPTION. Fulvous, 4 spots in transverse row on prothorax (Fig. 3), scutellum, very small spot on basal margin of elytra, elongate spot on each side of pygidium and preceding tergite, two spots on each side of abdominal sternites 1-3 and one spot on each side of abdominal sternite 4 (Fig. 4) black. $11^{\text {th }}$ antennal segment darkened on apex. Body elongate ovate. Head with interantennal space convex, frontal tubercles subquadrate and microsculptured, vertex finely and sparsely punctate, interocular space about 1.3 times wider than transverse diameter of eye. Antennae thin and long, reach posterior third of elytra, proportions of segments are as 9-3-4-8-10-10-10 $7-7-7-7$, preapical segments about 5 times as long as wide. Prothorax 1.7 times as wide as long, broadest near base and feebly narrowed anteriorly, with straight side margins, surface without distinct impressions, shining, densely punctate. Scutellum triangular with rounded apex, shining and impunctate. Elytra 1.4 times as long as wide, broadest in posterior quarter, surface shining, without impressions, with dense and moderately strong punctures and with hairs along apical margin. Pygidium and preceding tergite not covered by elytra. Segment 1 of hind tarsus more than twice as long as next segments united. Length of body $5.2 \mathrm{~mm}$.

DIAGNOSIS. This species differs well from all continental species of this genus with transverse rows of black spots on prothorax and abdominal segments.

\section{Monolepta fedorenkoi L.Medvedev, sp.n.} Fig. 5.

MATERIAL. Holotype (female): Vietnam, Binh Phuoc prov., Bu Gia Map National Park, 12-24.IV.2009, leg. D. Fedorenko (LM). Paratype: same locality and date, 1 female (LM).

DESCRIPTION. Pale fulvous, labrum, palpi, and stripe between eyes covering frontal tubercles, antennae and apices of tarsi black. Body elongate ovate. Head impunctate. Labrum with straight anterior margin, microsculptured, clypeus with straight anterior margin, interantennal space convex, frontal tubercles transverse with acute anterior angles, delimited behind with straight impression, interocular space almost twice as wide as transverse diameter of eye. Antennae reach behind middle of elytra, proportions of segments are as 16-5-6-16-16-16-14 14-13-11-16, preapical segments about 4 times as long as wide. Prothorax 1.5 times as wide as long, broadest near middle, sides feebly rounded, surface finely and not distinctly punctate, impressed on each side. Scutellum triangular, microsculptured. Elytra 1.7 times as long as wide, finely and densely punctate. Spermatheca- fig. 5. Segment 1 of hind tarsus almost as long as next segments united. Length of body $3.8-4.5 \mathrm{~mm}$.

DIAGNOSIS. Near M. lauta Gressitt \& Kimoto, 1963, differs with black antennae, distinct impressions on prothorax and black stripe on head; from other fulvous species $-M$. severini (Jacoby, 1896) and nearest species differs immediately with unusual color of head and entirely black antennae.

\section{Monolepta binhphuoca L. Medvedev, sp.n.} Fig. 11.

MATERIAL. Holotype (male): Vietnam, Binh Phuoc prov., Bu Gia Map National Park, 12-24.IV.2009, leg. D. Fedorenko (LM).

DESCRIPTION. Light fulvous, head red, antennae fulvous with segments 6-11 more or less darkened on apex, scutellum, humeral part of elytra including corresponding part of epipleurae (Fig. 11), and breast black, abdomen fulvous with pygidium and apical sternite black except bases, tibiae and tarsi black. Body elongate. Head impunctate except a few sparse punctures on vertex, clypeus elongate triangular with convex central part prolonged into interantennal space, frontal tubercles triangular, microsculptured, delimited posteriorly with straight impressed part, interocular space distinctly wider than transverse diameter of eye. Antennae thin and long, reach apical slope of elytra, proportions of segments are as $10-3-5-10-10-10-10-10-10-$ 9-12, preapical segments about 6 times as long as wide. Prothorax 1.7 times as wide as long, broadest before base, with almost straight side margins, surface without impressions, shining and impunctate. Scutellum triangular with rounded apex, finely microsculptured. Elytra 1.8 times as long as wide, finely punctate, with round common impression (diameter $1.3 \mathrm{~mm}$ ) placed a little behind scutellum; anterior part of suture in this impression distinctly elevated. Segment 1 of fore and mid tarsi not widened. I don't extract aedeagus, because the specimen is not fully matured. Length of body $5.0 \mathrm{~mm}$.

DIAGNOSIS. There are 5 species in Indochina with modified elytra of male, 3 of them in Vietnam [Kimoto, 1989]. A new species is near $M$. vietnamica Kimoto, 1989, but differs by color of elytra and abdomen, more transverse prothorax, larger size and with elongate, not round impression on elytra.

\section{Monolepta daklaka L. Medvedev, sp.n.}

MATERIAL. Holotype (female): Vietnam, Dak Lak province, Chu Yang Sin Nam Park (12 $23^{\circ} 48^{\prime \prime}$ N, $108^{\circ} 20^{\prime} 59^{\prime \prime}$ ), 1000 m, upper flow of Krong Kmar, 30.III-14.IV.2012, on light, leg. D. Fedorenko (LM).

DESCRIPTION. Fulvous, head except vertex, antennae including basal segments, tibiae and tarsi black. 


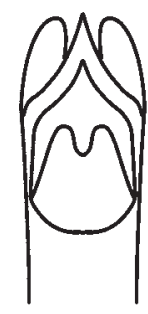

12

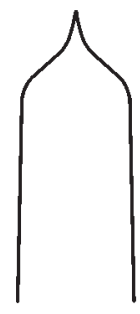

13

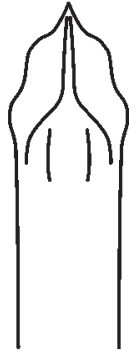

14

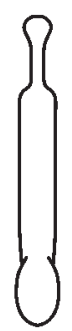

15

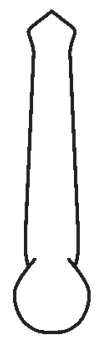

16

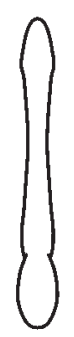

17

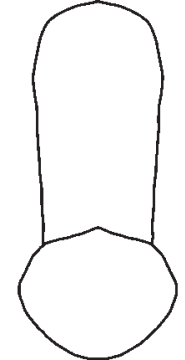

18

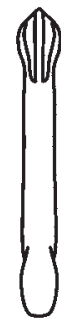

19

Figs 12-19. Aedeagus :12 - Platycorynus splendens sp.n.; 13 - Colaspoides fulvus sp.n.; 14 - Colaspoides pseudorufa sp.n.; 15 Monolepta mirabilis sp.n.; 16 - Sermyloides nigricollis sp.n.; 17 - Vietoluperina polilovi gen. et sp.n.; 18 - Aplosonyx fedorenkoi sp.n.; 19 - Theopea clypealis sp.n.; 12 - dorsal view; 13-19 — ventral view.

Рис 12-19. Эдеагус :12 - Platycorynus splendens sp.n.; 13 - Colaspoides fulvus sp.n.; 14 - Colaspoides pseudorufa sp.n.; 15 Monolepta mirabilis sp.n.; 16 - Sermyloides nigricollis sp.n.; 17 - Vietoluperina polilovi gen. et sp.n.; 18 - Aplosonyx fedorenkoi sp.n.; 19 - Theopea clypealis sp.n.; 12 - сверху; 13-19 - снизу.

Body elongate ovate. Head distinctly punctate on clypeus and very finely on vertex, frontal tubercles triangular, convex, finely microsculptured, delimited posteriorly with sharp transverse impression, interantennal space narrow, interocular space a little narrower than transverse diameter of eye. Antennae reach apical third of elytra, proportions of seg-

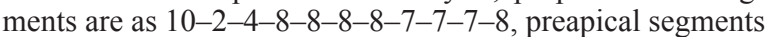
about 4 times as long as wide. Prothorax 1.4 times as wide as long, broadest in middle, with rounded side margins, surface convex, without depressions and practically impunctate. Scutellum triangular, equidistant, impunctate. Elytra 1.45 times as long as wide, broadest in posterior third, surface finely and densely punctate. Length of body $4.2 \mathrm{~mm}$.

DIAGNOSIS. This species differs from all continental species of the genus with combination of 4 characters: 1 head black except vertex, 2 - antennae entirely black, 3 tibiae and tarsi black, 4 - prothorax without impressions. Resembles a little M. nigrifrons (Allard, 1889) but differs in form and structure of prothorax, feeble punctures of elytra and paler upperside.

\section{Sermyloides nigricollis L. Medvedev, sp.n.} Fig. 16.

MATERIAL. Holotype (male): Vietnam, prov. Gialai-Contum, Buon-Loi, $40 \mathrm{~km} \mathrm{~N}$ Ankhe, 20.VI.1980, tropical forest, leg. L. Medvedev (LM)

DESCRIPTION. Fulvous, antennae except basal segment, prothorax, breast and femora black, posterior tibiae partly darkened, excavation of eyes white.

Body ovate. Head impunctate, deeply grooved before antennal bases, having in anterior part of this groove a pair of small tubercles and elevated sharp anterior margin; frontal tubercles short and transverse, distinctly delimited posteriorly, interocular space about 3 times as wide as transverse diameter of eye. Antennae reach behind middle of elytra, proportions of segments are as 14-2-12-10-10-10-9-8-76-6, preapical segments about 3-4 times as long as wide, segment 3 slightly curved. Prothorax 2.35 times as wide as long, broader at base, side margins rounded, hind margin arcuate, surface without any impressions, very thinly microsculptured, with distinct sparse punctures. Scutellum triangular, impunctate. Elytra 1.4 times as long as wide, broadest behind middle, with broadly rounded apices, surface with round groove at base between feeble humeral tubercle and scutellum, densely and moderately strongly punctuate, with microsculptured interspaces. Aedeagus (Fig. 16) moderately curved in lateral view. Length of body $5.8 \mathrm{~mm}$.
DIAGNOSIS. Differs well from all continental species in having black prothorax and unusual white spot near eye.

Sermyloides tamdaoana L. Medvedev, sp.n.

MATERIAL. Holotype (female): Vietnam, Tam Dao, 900 m, 4.VI.1981, leg. L. Medvedev (LM).

DESCRIPTION. Fulvous, antennae (except base and underside of basal segment), apices of hind femora, all tibiae and tarsi black, apical half of elytra with large white spot, not touching margins. Body elongate ovate. Head impunctate, with deep concavity before antennal bases, frontal tubercles strongly transverse, narrow, divided posteriorly with deep impression, anterior margin of clypeus straight, interocular space about 3 times as wide as transverse diameter of eye. Antennae reach behind middle of elytra, proportions of segments are as 14-2-11-11-10-10-8-8-8-6-7, preapical segments about 3-4 times as wide as 2, segment 3 not curved. Prothorax 2.35 times as wide as long, broader before base, side margins slightly rounded, hind margin arcuate, surface densely microsculptured, with very fine and sparse, almost indistinct punctures. Scutellum elongate-triangular, with a few punctures. Elytra 1.55 times as long as wide, broader in apical third, apices broadly rounded, surface rather strongly and densely punctuate, humeral tubercle feeble, poorly delimited posteriorly. Length of body $6.7 \mathrm{~mm}$.

DIAGNOSIS. Near S. semiornata Chen, 1942 from West China, differs with head and prothorax practically impunctate, body much larger, light area on elytra not margined with black, tibiae and tarsi black, upperside without metallic luster.

Vietoluperina L. Medvedev, gen.n.

Type of genus: $V$. polilovi L.Medvedev, sp.n.

DESCRIPTION. Body elongate ovate. Antennal insertions touch inner margin of eye, interantennal space 1.4 times as wide as length of basal antennal segment, flat, not bordered on sides, clypeus indistinctly widened from frons. Labrum not bilobed apically. Genae $1 / 5$ as deep as eyes. Prothorax strongly transverse, without impressions, anterior margin slightly marginate only on sides, lateral and posterior margins distinctly marginate. Elytra confusedly punctate. Anterior coxal cavities closed, prosternal process distinctly elevated between anterior coxae. Apex of hind tibia without spur, with dark ridge on each side and short setae mostly between these ridges. Segment 1 of hind tarsus almost as long as next segments united. Claws appendiculate.

DIAGNOSIS. This genus is near genera with closed anterior coxal cavities and broad interantennal space: Vieto- 
luperus L. Medvedev et Dang Dap, 1981 and Cassenoides Kimoto, 1989. They differ as follow:

1(2) Hind tibiae with spurs. Clypeus sharply delimited from frons. Elytra with irregular rows of punctures ............... ............. Vietoluperus L.Medvedev \& Dong Dap 1981

2(1) Hind tibiae without spurs. Elytra confusedly punctate.

3(4) Apexes of hind tibiae with ridges on sides and short setae mostly between ridges. Clypeus not divided from frons Vietoluperina gen. $\mathbf{n}$.

4(3) Apexes of hind tibiae without lateral ridges, only with setae. Clypeus divided from frons

Cassenoides Kimoto 1989.

\section{Vietoluperina polilovi L. Medvedev, sp.n.} Fig. 17.

MATERIAL. Holotype (male): Vietnam, Binh Phuoc prov., Bu Gia Map National park, IV.2009, leg. A. Polilov (LM).

Paratypes: same locality and date, 2 females (LM), S. Vietnam, Lam Dong prov., Bi Doup-Nui Ba National Park, env. Long Lanh, $12^{\circ} 10^{\prime} 44^{\prime} \mathrm{N}, 108^{\circ} 40^{\prime} 44 ” \mathrm{E}, 1400-1600 \mathrm{~m}, 27 . \mathrm{IV}-9 . V .2009$, leg. D. Fedorenko, 1 female (LM).

DESCRIPTION. Fulvous, antennal segments 4-11 with black apices to black with fulvous bases, scutellum black, elytra with black margins, tarsi black, one paratype with entirely fulvous scutellum and elytra. Body elongate and almost parallel-sided. Head practically impunctate, anterior margin of labrum and clypeus straight, frontal tubercles subquadrate, divided by space larger than size of tubercle, interocular space 2.5 times broader than transverse diameter of eye. Antennae thin, reach anterior quarter of elytra, proportions of segments are as 11-3-9-11-9-11-11-11, next segments absent, preapical segments about 6 times as long as wide. Prothorax 2.3 times as wide as long, anterior margin very narrowly marginate on sides, unmargined in middle, side margins feebly rounded, surface shining, very finely and sparsely punctate. Scutellum triangular, with a few fine punctures. Elytra 1.4 times as long as wide, densely punctate, with interspaces mostly smaller than diameter of punctures. Epipleurae not broad, narrowed to behind and disappear near $3 / 4$ of elytral length. Aedeagus (Fig. 17) thin and long. Length of male $7.7 \mathrm{~mm}$, of female $7.8-9.1 \mathrm{~mm}$.

\section{Aplosonyx fedorenkoi L. Medvedev, sp.n.} Fig. 18.

MATERIAL. Holotype (male): South Vietnam, Lam Dong prov., Bi Doup-Nui Ba Natural Reservation, env. Long Lanh, 12 $10^{\prime} 44^{\prime}$ 'N, 108 40'44' E, 1400-1600 m, 27.IV-9.V.2009, leg. D. Fedorenko (LM).

Paratype: same locality and date, 1 male (LM).

DESCRIPTION. Entirely fulvous.

Head impunctate except hind part of vertex, having sparse punctures and very thin microsculpture, frontal tubercles transverse, distinctly raised, microsculptured, delimited posteriorly with slightly arcuate groove, vertex with deep longitudinal impression in anterior part, interocular space almost 1.5 times as wide as transverse diameter of eye. Antennae reach middle of elytra, slender, proportions of segments are as 20-7-5-35-30-27-26-25-25-25-30, preapical segments about 3 times as long as wide. Prothorax twice as wide as long, side margins practically straight and parallel-sided, posterior margin very feebly arcuate, surface shining, finely punctate, with deep transverse depression in middle. Scutellum triangular, microsculptured, with a few fine punctures. Elytra 1.4 times as long as wide, with side margins slightly rounded, surface densely and confusedly punctate, without postbasal impression, interstities of punctures mostly compa- rable with diameter of punctures. Apical abdominal sternite trilobed, with deeply grooved central lobe. Aedeagus (Fig. 18) without any sculpture on underside, apical quarter in lateral view distinctly curved downwards. Length of body 6.8-7.2 mm.

DIAGNOSIS. Near A. spenceri Kimoto, 1989 from Cambodia, but almost twice smaller and aedeagus with rounded apex and apical part distinctly curved downwards.

\section{Theopea clypealis L. Medvedev, sp.n.} Fig. 19.

MATERIAL. Holotype (male): South Vietnam, Dongnai prov., Cat Tian, V.2009, leg. A. Polilov (LM).

Paratypes: same locality, 2 males (LM)

DESCRIPTION. Metallic green or bluish green, underside of head, all palpi, labrum, clypeus except sides, antennae except dark apical segment and legs fulvous, abdomen dark fulvous with more or less metallic luster. Clypeus modified: its fulvous part deeply concave with tubercle in middle. Interantennal area elevated, longitudinally concave and ridged on sides, these ridges are the prolongation of triangular frontal tubercles, which are impunctate, shining, moderately convex and poorly delimited posteriorly. Vertex distinctly punctate and microsculptured, interocular space about 3 times as wide as transverse diameter of eye. Antennae almost reach apex of elytra, proportions of segments are as 13-3-8-10 10-9-9-9-9-8-10, preapical segments about 3-4 times as long as wide. Prothorax 1.2 times as wide as long, broadest before apex, sides very feebly rounded, surface with deep transverse impression on each side, distinctly punctate, with finely microsculptured interspaces. Scutellum triangular with rounded apex, impunctate. Elytra twice as long as wide, parallel-sided, surface closely impressed by strong punctured arranged in rows, their interspaces smooth, longitudinally costate till the apex. Segment 1 of anterior tarsi feebly widened, elongate. Aedeagus thin and long, almost straight in lateral view (Fig. 19). Length of body 5.5-5.9 mm.

DIAGNOSIS. Differs from all continental species of the genus with bicolor head and modified clypeus of male.

Plagiodera miniaticollis (Hope, 1831)

MATERIAL. Vietnam, Lam Dong prov., $35 \mathrm{~km} \mathrm{NW}$ of Bao

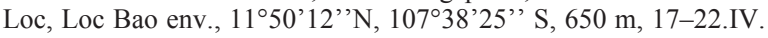
2012, at light, leg. D. Fedorenko, 1 ex. (LM).

REMARK. Species was known from Nepal, North India and Myanmar. A specimen from Vietnam has a small spot on vertex and poorly delimited M-like spot on prothorax. Very possibly this species might be removed to Plagiosterna Motschulsky, 1860.

\section{Sinocrepis obscurofasciata (Jacoby, 1882)}

MATERIAL. Vietnam, prov. Gia-Lai-Contum, $40 \mathrm{~km}$ N Ankhe, Son Lang [=Buon Loi], 25.XI-4.XII.1978, leg. L. Medvedev, 3 ex.; same locality, $50 \mathrm{~km} \mathrm{~N}$ Ankhe, Ha-Nung, 11.XI.1979, leg. L. Medvedev.

REMARK. This genus and species is firstly recorded for Vietnam. It was known from Sri Lanka, South India, Myanmar, Thailand, Laos, China and Taiwan [Medvedev, 2009].

\section{References}

Kimoto Sh. 1989. Chrysomelidae of Thailand, Cambodia, Laos and Vietnam. VI. Galerucinae // Esakia. Vol.27. P.1-241.

Medvedev L.N. 2003. Revision of the genus Colaspoides Laporte (Chrysomelidae, Eumolpinae) from continental Asia // Russian Entomological Journal. Vol.12. No.3. P.257-297

Medvedev L.N. 2009. Alticinae of Indochina. Moscow: KMK Scientific Press. 224 p. 